\title{
UJI HEDONIK BISKUIT CANGKANG KERANG SIMPING (Placuna placenta) DARI PERAIRAN INDRAGIRI HILIR
}

\author{
R. Marwita Sari Putri ${ }^{(1)}$ dan Hermiza Mardesci ${ }^{(2)}$ \\ ${ }^{(1)}$ Program Studi Teknologi Hasil Perikanan, Fakultas Ilmu Kelautan dan Perikanan, \\ Universitas Maritim Raja Ali Haji. Jalan Politeknik Senggarang, Kampus UMRAH \\ Senggarang Tanjungpinang, Kepulauan Riau, Hp +6281364548648 \\ ${ }^{(2)}$ Program Studi Teknologi Pangan Universitas Islam Indragiri. Jalan Lintas \\ Provinsi Parit 1, Tembilahan, Indragiri Hilir
}

witaumrah@ac.id

\begin{abstract}
Abstrak
Uji hedonik merupakan tanggapan pribadi panelis tentang kesukaan atau ketidaksukaannya terhadap komoditi yang dinilai, bahkan tanggapan dengan tingkatan kesukaan atau tingkatan ketidaksukaannya dalam bentuk skala hedonik. Tujuan dari penelitian ini adalah untuk mengetahui uji hedonik dan kandungan nutrisi terhadap biskuit cangkang kerang simping (Placuna placenta) yang berasal dari perairan Indragiri Hilir. Biskuit cangkang kerang simping yang terpilih berdasarkan uii hedonik dari 20 orang panelis semi terlatih adalah $50 \%$ kosentrasi tepung cangkang kerang simping. Berdasarkan nilai nutrisi biskuit cangkang kerang simping dari Perairan Indragiri hilir bahwa cangkang kerang simping dapat dijadikan sebagai alternative pangan yang mengandung kalsium.
\end{abstract}

Kata Kunci : Placuna placenta, uji hedonik, panelis, kalsium

\section{PENDAHULUAN}

Moluska adalah hewan bertubuh lunak yang terlindungi oleh lapisan mantel. Banyak spesies moluska yang memiliki cangkang kapur pelindung yang menyatu dengan mantel. Filum Moluska terdiri lebih dari 100.000 spesies dengan variasi bentuk tubuh dan cara hidup. Beberapa jenis moluska merupakan komoditi perikanan yang potensial untuk dikembangkan. Salah satu komoditi perikanan yang mempunyai nilai ekonomis untuk dikembangkan adalah kerang simping, Placuna placenta (Linnaeus, 1758), atau juga dikenal dengan nama Window-pane oyster, atau Kapis (Phillipina), dan Methy (India), termasuk dalam Filum Mollusca, Kelas Pelecypoda, serta Famili Placunidae. Kerang Simping memiliki dua cangkang yang bundar, halus, tipis, pipih, serta sedikit transparan. Diameter cangkang dari spesies ini dapat mencapai $150 \mathrm{~mm}$. Hidup di perairan sebagai hewan benthik. Seperti bivalvia lainnya, simping merupakan filter feeder yang menyaring partikel makanan melalui insang (Campbell 2007). Kerang mengandung mineral makro yang berguna untuk kesehatan. Fungsi mineral secara umum adalah untuk mengatur keseimbangan asam basa tubuh, berperan dalam metabolisme, unsur pembentuk enzim, berperan dalam fungsi otot dan saraf (Almatsier 2006).

Kerang Simping ditemukan dalam substrat lumpur dan pasir berlumpur di perairan dangkal. Perairan Indragiri Hilir merupakan salah satu tempat 
ditemukannya kerang simping ini. Potensi limbah berupa cangkang kerang belum banyak termanfaatkan termasuk cangkang dari kerang simping. Selama ini limbah padat kerang berupa cangkang hanya dimanfaatkan sebagai salah satu materi hiasan dinding, hasil kerajinan, atau bahkan sebagai campuran pakan ternak namun belum dimanfaatkan secara maksimal, padahal potensinya sebagai sumber kalsium tinggi dapat dijadikan sebagai terobosan baru.

Beberapa penelitian menunjukkan bahwa cangkang kerang mengandung senyawa kalsium yang berpotensi sebagai suplemen tulang alamiah pencegah osteoporosis (Firmansyah 2005). Kerupuk dengan penambahan cangkang kerang hijau mempunyai kandungan kalsium sebesar 2575,35 $\mathrm{mg} / 100 \mathrm{~g}$. Tingginya kalsium pada kerang hijau bersumber dari komponen penyusun cangkang kerang hijau yang berupa kapur ( $\mathrm{CaCO} 3)$ dengan lapisan yang melindungi tubuh kerang atau disebut dengan lapisan periostracum dan zat tanduk pada cangkang (Permana et al. 2006). Melihat banyaknya kandungan kalsium yang terkandung didalam cangkang kerang, sehingga diperlukan upaya dalam pemanfaatan limbah tersebut berupa diversifikasi produk pangan yang diformulasikan dalam bentuk tepung sebagai sumber kalsium dan dapat diaplikasikan sebagai bahan fortifikasi dalam proses pembuatan biskuit.

Biskuit merupakan produk makanan yang dibuat dari bahan dasar terigu yang dipanggang hingga kadar air kurang dari $5 \%$. Biskuit adalah produk bakeri kering yang dibuat dengan cara memanggang adonan yang terbuat dari tepung terigu dengan atau subtitusinya, minyak atau lemak, dengan atau tanpa penambahan bahan pangan lain dan bahan tambahan pangan yang diizinkan (BSN 2011). Produk ini sudah dikenal luas oleh masyarakat sebagai camilan. Dengan adanya pemanfaatan cangkang kerang simping yang dibuat tepung kalsium dan diaplikasikan sebagai bahan tambahan dalam pembuatan biskuit diharapkan dapat meningkatkan nilai tambah (added value) yang berguna bagi masyarakat.

Adapun tujuan dari penelitian ini adalah untuk mengetahui uji hedonik dan kandungan nutrisi terhadap biskuit cangkang kerang simping yang dihasilkan.

\section{METODOLOGI PENELITIAN}

\section{Bahan}

Bahan utama yang diperlukan dalam penelitian ini adalah kerang simping yang didapat dari perairan Indragiri Hilir Tembilahan dan bahanbahan yang digunakan untuk pembuatan biskuit yaitu mentega, room buter, gula halus, vanili, baking powder, telur, tepung terigu, tepung maizena, susu bubuk, pewarna tetrazine.

\section{Alat}

Peralatan yang digunakan untuk pembuatan tepung cangkang kerang simping adalah oven biasa, alat penepungan (Hammer mill, Conduk 6400), wadah coolbox (stryofoam), pisau, baskom, timbangan analitik, $\mathrm{pH}$ meter.

Peralatan yang digunakan untuk pembuatan biskuit adalah alat-alat uji organoleptik, kompor, panci, spatula, blender, ayakan, toples, timbangan, mixer, loyang, oven, cetakan kue.

Bahan kimia yang digunakan adalah bahan-bahan kimia yang digunakan untuk analisis kadar air, kadar abu, kadar lemak, kadar protein, dan analisa kalsium yaitu pelarut immicible, pereaksi toluene, $\mathrm{K}_{2} \mathrm{SO}_{4}, \mathrm{HgO}$, tablet 
kjeltab, $\mathrm{NaOH}, \mathrm{Na}_{2} \mathrm{SO}_{3}, \mathrm{H}_{2} \mathrm{BO}_{3}, \mathrm{HCL}$ $0,02 \mathrm{~N}$, pelarut dietil eter, $\mathrm{KMnO} 4$, amonium oksalat jenuh, indikator merah metil, amoniak encer, asam asetat dan $\mathrm{AgNO}_{3}$

\section{Pengukuran Potensi Limbah Kerang Simping}

Kerang simping yang telah diperoleh dari nelayan harus dalam keadaan segar lalu dilakukan penimbangan agar diperoleh data berat kerang simping utuh, setelah itu dilakukan pencucian untuk menghilangkan kotoran pada bagian permukaan dan bagian dalam dari tubuh kerang simping. Kemudian dilakukan perebisan pada suhu kurang dari $100{ }^{\circ} \mathrm{C}$ selama 15 menit dengan tujuan untuk memudahkan dalam pemisahan cangkang dari tubuh kerang simping. Dilakukan pemisahan menjadi tiga bagian yaitu cangkang, daging dan jeroan. Cangkang kerang yang sudah terpisah dilakukan penimbangan untuk mengetahui rendemen dari kerang simping utuh. Lalu dilakukan prosedur pembuatan tepung cangkang kerang simping. Setelah diperoleh tepung cangkang dilakukan penimbangan untuk memperoleh rendemen dari tepung cangkang kerang simping. Skema alur proses penelitian pada tahap ini dapat dilihat pada Gambar 1.

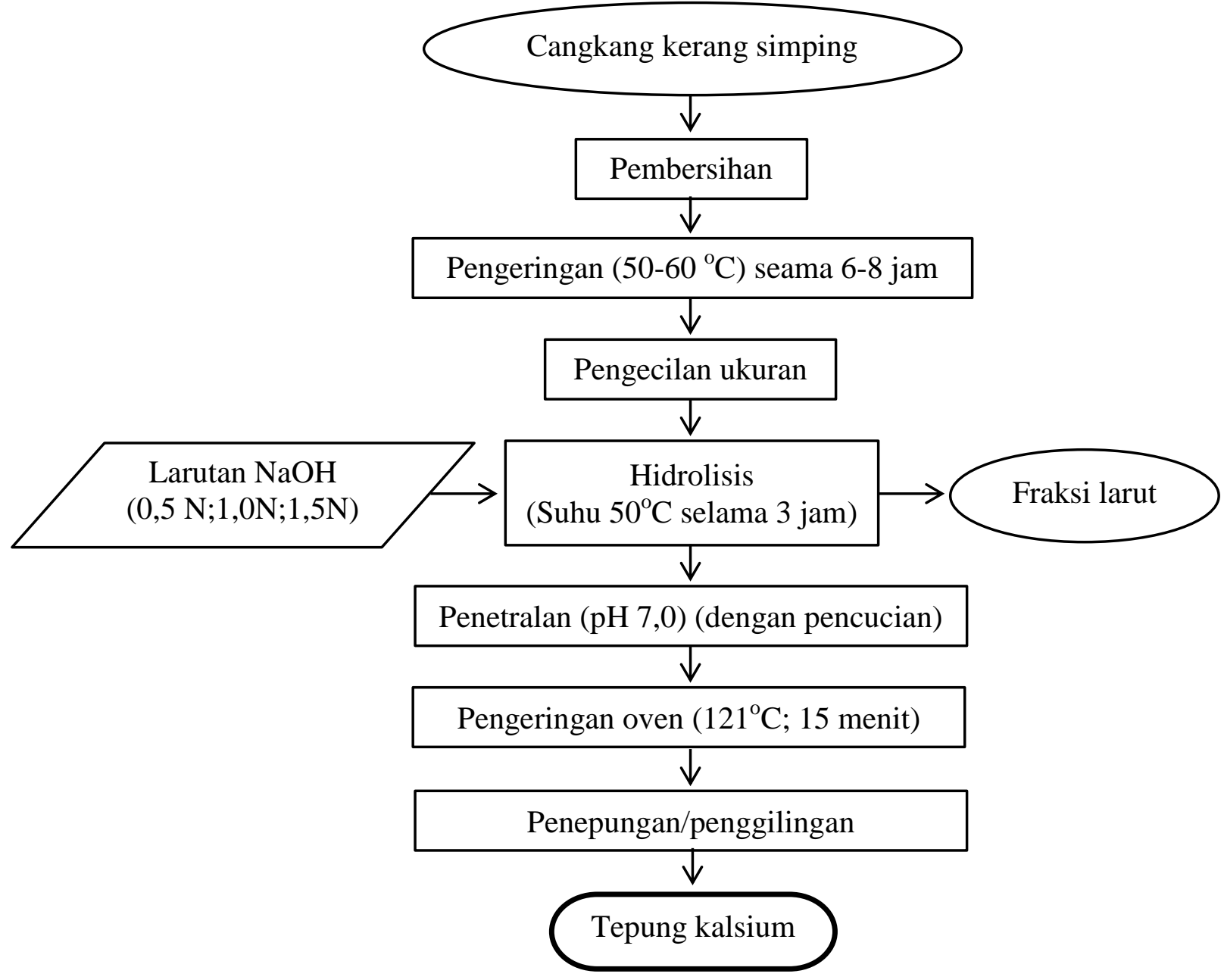

Gambar 1. Skema pemisahan kalsium dari cangkang kerang simping (Placuna placenta) (Modifikasi Sada 1984). 
Pembuatan Biskuit dengan Penambahan Kosentrasi Tepung Kalsium Cangkang Kerang Simping

Pembuatan biskuit dengan penambahan tepung kalsium cangkang kerang simping yang kemudian diuji organoleptik untuk mengetahui formula biskuit yang diinginkan. Untuk pembuatan biskuit tepung kalsium cangkang kerang simping dalam penelitian ini ditetapkan urutan pembuatan biskuit sebagai berikut: Margarin (125g), room butter $(10 \mathrm{~g})$ dan baking powder (5g) sampai mengembang. Lalu masukan kuning telur (satu butir) dan diaduk dengan mixer sehingga rata. Kemudian kedalam adonan dimasukkan tepung terigu, tepung kalsium cangkang kerang simping dengan konsentrasi A (0\%), B (25\%), C (50\%), D (75\%), E (100\%), tepung maizena, pewarna tartrazine, susu bubuk lalu diaduk hingga homogen. Setelah adonan homogen dan mudah dibentuk, dicetak dengan sendok, letakkan diatasnya choccholate chip lalu dipanggang dalam oven pada suhu $160^{\circ} \mathrm{C}$ selama 15 menit. Skema alur penelitian pada tahap ini dapat dilihat pada Gambar 2.

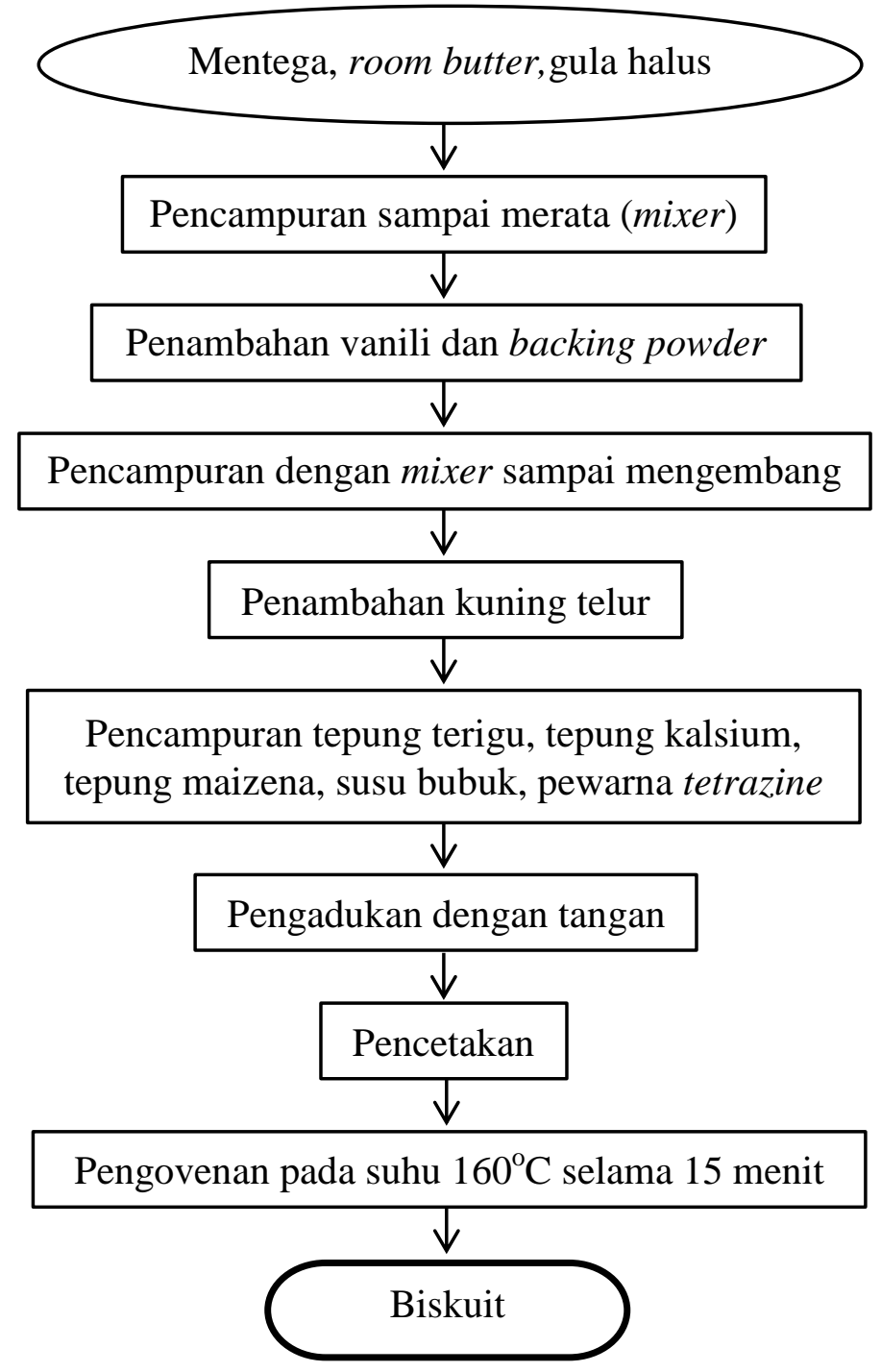

Gambar 2. Prosedur pembuatan biskuit dengan penambahan tepung kalsium cangkang kerang simping (Placuna placenta) (Modifikasi dari Hiswaty 2002). 


\section{HASIL DAN PEMBAHASAN}

\section{Rendemen}

Rendemen merupakan persentase bahan baku utama yang menjadi produk akhir atau perbandingan produk akhir dengan bahan baku utama.

Berat awal cangkang kerang simping adalah $4 \mathrm{~kg}$, kemudian cangkang tersebut dibersihkan dari kotoran dan dikeringkan sehingga beratnya menjadi $3,8 \mathrm{~kg}$. Rendemen tepung cangkang kerang simping yang dihasilkan adalah 58,4\%. Adapun tepung cangkang kerang simping yang dihasilkan adalah $1.87 \mathrm{~kg}$. Rendemen tepung cangkang kerang simping yang dihasilkan tinggi karena hampir semua bagian cangkang kerang simping yang digunakan dalam proses pembuatan tepung. Bentuk bahan baku dapat dilihat pada Gambar 3. rendemen tepung cangkang kerang simping berhubungan dengan metode pembuatan tepung cangkang kerang simping. Tahap-tahap proses pembuatan tepung cangkang kerang simping meliputi pengeringan, pengecilan ukuran, penggilingan dan penyaringan.

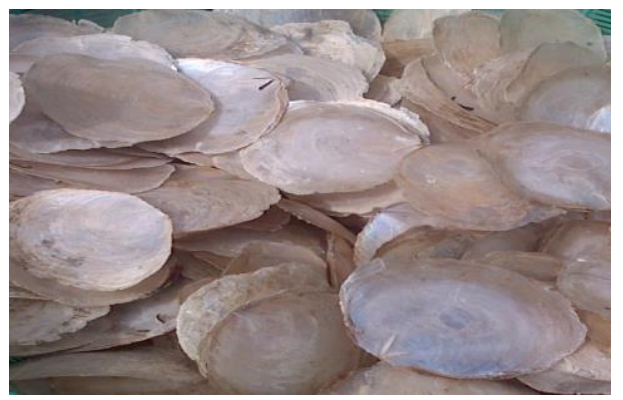

Gambar 3. Bahan baku utama yaitu cangkang kerang simping (Placuna Placenta) dari Perairan Indragiri Hilir

\section{Uji Hedonik terhadap Cangkang Kerang Simping}

Uji hedonik merupakan sebuah pengujian dalam analisa sensori organoleptik yang digunakan untuk mengetahui besarnya perbedaan kualitas diantara beberapa produk sejenis dengan memberikan penilaian atau skor terhadap sifat tertentu dari suatu produk dan untuk mengetahui tingkat kesukaan dari suatu produk (Tarwendah 2017). Tingkat kesukaan ini disebut skala hedonik, misalnya sangat suka, suka, agak suka, agak tidak suka, tidak suka, sangat tidak suka dan ain-lain (Stone dan Joel 2004). Uji kesukaan digunakan untuk mengukur kesukaan, biasanya dalam jangka waktu penerimaan atau preferensi tetentu. Dalam uji hedonik menggunakan jumlah responden yang cukup banyak
(Saxby 1996). Prinsip uji hedonik yaitu panelis diminta tanggapan pribadinya tentang kesukaan atau ketidaksukaannya terhadap komoditi yang dinilai, bahkan tanggapan dengan tingkatan kesukaan atau tingkatan ketidaksukaannya dalam bentuk skala hedonik. Dalam penganalisisan, skala hedonik ditransformasi menjadi skala numerik dengan angka menurut tingkat kesukaan. Aplikasi dalam bidang pangan dalam bidang pangan untuk uji hedonik ini digunakan dalam hal pemasaran, yaitu untuk memperoleh pendapat konsumen terhadap produk baru, hal ini diperlukan untuk mengetahui perlu tidaknya perbaikan lebih lanjut terhadap suatu produk baru sebelum dipasarkan, serta untuk mengetahui produk yang paling disukai oleh konsumen (Susiwi, 2009). 
Dalam penelitian ini dilakukan uji penerimaan dimana setiap panelis diharuskan mengemukakan tanggapan pribadinya terhadap produk yang disajikan. Tujuan uji ini adalah untuk mengetahui tingkat kesukaan atau penerimaan panelis terhadap biskuit cangkang kerang simping yang dibuat. Uji penerimaan yang dilakukan adalah uji hedonik dengan menggunakan 20 orang panelis semi terlatih. Pada uji ini panelis diminta mengungkapkan tanggapan pribadinya terhadap warna, rasa tekstur dan aroma biskuit. Tanggapan tersebut berupa kesan suka atau ketidaksukaan dan panelis juga diminta mengemukakan tingkat kesukaannya (skala hedonik). Pada uji hedonik produk biskuit ini, skala hedonik yang digunakan adalah 1-3, dimana angka $1=$ tidak suka, $2=$ netral, $3=$ suka.

Setelah pembuatan tepung cangkang kerang simping kemudian dilanjutkan dengan pembuatan biskuit. Dalam penelitian ini dilakukan suplementasi tepung tulang cangkang kerang simping ke dalam biskuit dengan kosentrasi tepung cangkang kerang simping sebagai berikut: $0 \%$ (A), $25 \%$ (B), $50 \%$ (C), $75 \%$ (D) dan $100 \%$ (E). Konsentrasi tepung cangkang kerang simping ini diukur berdasarkan berat tepung terigu. Kemudian dilakukan penilaian organoleptik (skala hedonik) terhadap warna, aroma, rasa dan kerenyahan untuk mengetahui penerimaan panelis terhadap biskuit. Karakteristik dari kenampakan umum produk meliputi warna, ukuran, bentuk, tekstur permukaan, tingkat kemurnian dan karbonasi produk (Meilgard et al.2006). Pada komoditi pangan warna mempunyai peranan yang penting sebagia daya tarik, tanda pengenal, dan atribut mutu (Tarwendah 2017).

\section{Warna}

Nilai warna digunakan dalam penilaian ini karena warna menentukan tingkat penerimaan produk oleh konsumen secara visual. Kenampakan merupakan parameter organoleptik yang penting karena sifat sensori yang pertama kali dilihat oleh konsumen (Soekarto 1990). Kesukaan konsumen terhadap produk pangan salah satunya dipengaruhi oleh atribut warna. Warna merupakan atribut organoleptik yang pertama dilihat oleh konsumen dalam membeli atau mengkonsumsi suatu produk (Apandi et al. 2016). Mutu bahan pangan pada umumnya tergantung pada beberapa faktor. faktor tersebut antara lain cita rasa, tekstur, nilai gizi, mikrobiologis, dan warna. Warna merupakan faktor yang penting untuk makanan, baik yang belum atau sudah diproses. Warna dengan rasa dan tekstur memainkan peran penting sebagai daya terima makanan tersebut. Selain itu, warna dapat memberikan tanda terjadinya perubahan kimia, seperti pencoklatan dan karamelisasi (deMan 1999). Sebelum faktor lain dipertimbangkan, secara visual faktor warna akan tampil terlebih dahulu. Suatu bahan pangan yang dinilai bergizi dan teksturnya sangat baik tidak akan dikonsumsi apabila memiliki warna yang tidak seharusnya (Winarno 2008). Penerimaan panelis terhadap nilai warna pada biskuit cangkang kerang simping disajikan pada Tabel 1 .

Penerimaan panelis terhadap nilai warna pada biskuit cangkang kerang simping berkisar antara suka-netral, nilai rata-rata tertinggi diperoleh pada perlakuan $\mathrm{C}$ (cokelat kekuningan) yaitu $50 \%$ panelis menyatakan suka dan nilai rata-rata terendah diperoleh pada perlakuan B (Cokelat) yaitu sekitar 60\% penalis menyatakan tidak suka. 
Tabel 1 . Tingkat Penerimaan Panelis terhadap Nilai Warna Biskuit Cangkang Kerang Simping

\begin{tabular}{llllllllllll}
\hline No & Karakteristik & \multicolumn{10}{c}{ Rata-rata jumlah panelis (Orang) } \\
\hline & & A & $\%$ & B & $\%$ & C & $\%$ & D & $\%$ & E & $\%$ \\
\hline 1 & Tidak suka & 10 & 50 & 12 & 60 & 7 & 35 & 9 & 45 & 10 & 50 \\
2 & Netral & 7 & 35 & 3 & 15 & 3 & 15 & 5 & 25 & 5 & 25 \\
3 & Suka & 3 & 15 & 5 & 25 & 10 & 50 & 6 & 30 & 5 & 25 \\
\hline
\end{tabular}

\section{Rasa}

Faktor yang sangat menentukan suatu produk dapat diterima atau tidak oleh konsumen adalah rasa. Rasa makanan merupakan campuran dari tanggapan cicip dan bau. Parameter rasa berbeda dengan aroma dan lebih banyak melibatkan panca indra pengecap. Rasa dipengaruhi oleh beberapa faktor antara lain senyawa kimia, konsentrasi, suhu dan interaksi dengan komponen rasa lainnya (Winarno 1997). Rasa (flavor) merupakan sensasi yang ditimbulkan oleh bahan di mulut, dirasakan terutama oleh indera rasa dan bau (deMan 1999). Rasa merupakan faktor penentu daya terima konsumen terhadap produk pangan. Rasa lebih banyak dinilai menggunakan indera pengecap atau lidah. Faktor rasa memegang peranan penting dalam pemilihan produk oleh konsumen, karena meskipun kandungan gizinya baik tetapi rasanya tidak dapat diterima oleh konsumen maka target meningkatkan gizi masyarakat tidak dapat tercapai dan produk tidak laku. Rasa lebih banyak melibatkan panca indera lidah. Penginderaan rasa dapat dibagi menjadi empat yaitu asam, asin, manis, dan pahit (Winarno 2008). Tabel tingkat penerimaan panelis terhadap nilai rasa disajikan pada Tabel 2 .

Penerimaan panelis terhadap nilai rasa pada biskuit cangkang kerang simping berkisar antara suka-netral, nilai rata-rata tertinggi diperoleh pada perlakuan $\mathrm{C}$ (tidak terasa cangkang kerang simping) yaitu $50 \%$ panelis menyatakan suka dan nilai rata-rata terendah diperoleh pada perlakuan A yaitu sekitar $50 \%$ panelis menyatakan tidak suka.

Tabel 2. Tingkat Penerimaan Panelis terhadap Nilai Rasa Biskuit Cangkang Kerang Simping

\begin{tabular}{llllllllllll}
\hline No & Karakteristik & \multicolumn{10}{c}{ Rata-rata jumlah panelis (Orang) } \\
\hline & & $\mathrm{A}$ & $\%$ & $\mathrm{~B}$ & $\%$ & $\mathrm{C}$ & $\%$ & $\mathrm{D}$ & $\%$ & $\mathrm{E}$ & $\%$ \\
\hline 1 & Tidak suka & 10 & 50 & 5 & 25 & 1 & 5 & 6 & 30 & 6 & 30 \\
2 & Netral & 4 & 20 & 7 & 35 & 9 & 45 & 11 & 55 & 8 & 40 \\
3 & Suka & 6 & 30 & 8 & 40 & 10 & 50 & 3 & 15 & 6 & 30 \\
\hline
\end{tabular}

\section{Tekstur}

Tekstur merupakan sensasi tekanan yang dapat diamati dengan mulut (pada waktu digigit, di kunyah, dan ditelan) atau pun perabaan dengan jari. Keadaan tekstur merupakan sifat fisik dari bahan pangan yang penting. Tekstur merupakan ciri suatu bahan sebagai akibat perpaduan dari beberapa sifat fisik yang meliputi ukuran, bentuk, jumlah dan unsur-unsur pembentukan bahan yang dapat dirasakan oleh indera peraba dan perasa, termasuk indera mulut dan penglihatan (Midayanto dan Yuwono 2014).Tekstur makanan merupakan hasil dari respon 
tactile sense terhadap bentuk rangsangan fisik ketika terjadi kontak antara bagian di dalam rongga mulut dan makanan. Tekstur dari suatu produk makanan mencangkup kekentalan/ viskositas yang digunakan untuk cairan newtonian yang homogen, cairan non newtonian atau cairan yang heterogen, produk padatan, dan produk semi solid (Meilgard et al. 2006). Tekstur merupakan ciri suatu bahan sebagai akibat perpaduan dari beberapa sifat fisik yang meliputi ukuran, bentuk, jumlah dan unsur-unsur pembentukan bahan yang dapat dirasakan oleh indera peraba dan perasa, termasuk indera mulut dan penglihatan (Midayanto dan Yuwono, 2014).Tekstur makanan merupakan hasil dari respon tactile sense terhadap bentuk rangsangan fisik ketika terjadi kontak antara bagian di dalam rongga mulut dan makanan. Tekstur dari suatu produk makanan mencangkup kekentalan/ viskositas yang digunakan untuk cairan newtonian yang homogen, cairan non newtonian atau cairan yang heterogen, produk padatan, dan produk semi solid (Meilgard et al.2006).

Penerimaan panelis terhadap nilai tekstur pada biskuit cangkang kerang simping berkisar antara suka-netral, nilai rata-rata tertinggi diperoleh pada perlakuan C yaitu $45 \%$ panelis menyatakan suka dan nilai rata-rata terendah diperoleh pada perlakuan A yaitu sekitar $20 \%$ panelis menyatakan suka.

Tabel 3. Tingkat Penerimaan Panelis terhadap Nilai Tekstur Biskuit Cangkang Kerang Simping

\begin{tabular}{llllllllllll}
\hline No & Karakteristik & \multicolumn{10}{c}{ Rata-rata jumlah panelis (Orang) } \\
\hline & & A & $\%$ & B & $\%$ & C & $\%$ & D & $\%$ & E & $\%$ \\
\hline 1 & Tidak suka & 9 & 45 & 5 & 25 & 3 & 15 & 5 & 25 & 7 & 35 \\
2 & Netral & 7 & 35 & 6 & 30 & 8 & 40 & 10 & 50 & 9 & 45 \\
3 & Suka & 4 & 20 & 9 & 45 & 9 & 45 & 5 & 25 & 4 & 20 \\
\hline
\end{tabular}

Aroma

Aroma makanan dapat menentukan kelezatan dari makanan itu sendiri. Aroma menjadi daya tarik tersendiri dalam menentukan rasa enak dari produk makanan. Aroma lebih banyak dipengaruhi oleh panca indera penciuman. Aroma merupakan bau dari produk makanan, bau sendiri adalah suatu respon ketika senyawa volatil dari suatu makanan masuk ke rongga hidung dan dirasakan oleh sistem olfaktori (Tarwendah 2017). Senyawa volatil masuk ke dalam hidung ketika manusia bernafas atau menghirupnya, namun juga dapat masuk dari belakang tenggorokan selama seseorang makan (Kemp et al.2009). Senyawa aroma bersifat volatil, sehingga mudah mencapai sistem penciuman di bagian atas hidung, dan perlu konsentrasi yang cukup untuk dapat berinteraksi dengan satu atau lebih reseptor penciuman. Pada umumnya, aroma yang dapat diterima oleh hidung dan otak merupakan campuran empat macam aroma, yaitu harum, asam, tengik, dan hangus (Winarno 2008). Disamping itu senyawa aroma memainkan peran penting dalam produksi penyedap, yang digunakan di industri jasa makanan, untuk meningkatkan rasa dan umumnya meningkatkan daya tarik produk makanan tersebut (Antara dan Wartini, 2014). Tabel tingkat penerimaan panelis terhadap nilai aroma disajikan pada Tabel 4. 
Penerimaan panelis terhadap nilai aroma pada biskuit cangkang kerang simping berkisar antara suka-netral, nilai rata-rata tertinggi diperoleh pada perlakuan C yaitu $40 \%$ panelis menyatakan suka dan nilai rata-rata terendah diperoleh pada perlakuan A yaitu sekitar $15 \%$ panelis menyatakan suka.

Tabel 4. Tingkat Penerimaan Panelis terhadap Nilai Aroma Biskuit Cangkang Kerang Simping

\begin{tabular}{llllllllllll}
\hline No & Karakteristik & \multicolumn{10}{c}{ Rata-rata jumlah panelis (Orang) } \\
\hline & & A & $\%$ & B & $\%$ & C & $\%$ & D & $\%$ & E & $\%$ \\
\hline 1 & Tidak suka & 10 & 50 & 12 & 60 & 9 & 45 & 9 & 45 & 7 & 35 \\
2 & Netral & 7 & 35 & 3 & 15 & 3 & 15 & 5 & 25 & 6 & 30 \\
3 & Suka & 3 & 15 & 5 & 25 & 8 & 40 & 6 & 30 & 7 & 35 \\
\hline
\end{tabular}

Nilai Gizi Biskuit Cangkang Kerang Simping yang Terpilih pada Uji Hedonik

Biskuit cangkang kerang simping yang terpilih berdasarkan uji hedonik dari parameter warna, rasa aroma dan tekstur adalah biskuit tepung cangkang kerang simping pada perlakuan C $(50 \%)$ Nilai gizi biskuit cangkang kerang simping di sajikan pada Tabel 5.

Kadar air biskuit cangkang kerang simping adalah $3,76 \%$, hal ini disebabkan karena semakin banyak konsentrasi tepung cangkang kerang simping yang ditambahkan maka akan semakin sedikit penambahan tepung terigu sehingga akan mengurangi daya mengikat air. Penambahan tepung cangkang kerang yang mengandung kalsium ini membuat daya ikat tepung terigu menurun karena penggunaan tepung terigu yang berkurang (Abidin et al. 2016). Kadar air biskuit cangkang kerang simping tidak melebihi kadar air biskuit berdasarkan SNI (2011) yaitu maksimal 5\%. Hal tersebut sesuai dengan Agustini et al. (2011), semakin tinggi konsentrasi tepung cangkang yang ditambahkan maka semakin kecil kadar air karena penambahan tepung cangkang akan mengakibatkan pengurangan penggunaan tepung terigu dalam adonan sehingga akan mengurangi daya mengikat air.

Kadar protein biskuit cangkang kerang simping adalah 19,09\% jumlah ini lebih tinggi jika dibandingkan dengan jumlah protein pada cookies dari cangkang telur. Jumlah kandungan mineral yang tinggi pada cangkang juga mempengaruhi jumlah protein yang dihasilkan (Rahmawati dan Nisa 2015). Berdasarkan SNI (2011) untuk syarat mutu jumlah protein biskuit minimal $5 \%$.

Kadar lemak biskuit cangkang kerang simping adalah 33,23\%. Jumlah ini lebih tinggi jika dibandingkan dengan cookies dari cangkang kerang simping (Amusium pleuronectes) yaitu 7,23\% (Agustini et al. 2011).

Kadar abu biskuit cangkang kerang simping adalah 4,39\%, jumlah ini lebih rendah jika dibandingkan dengan kadar abu pada cookies dari cangkang telur. Tingginya kadar abu pada cangkang telur ini disebabkan karena kadar abu dari tepung cangkang telur cukup tinggi, karena pada cangkang telur terdapat zat kapur $\left(\mathrm{CaCO}_{3}\right)$ sebagai bahan penyusun utama cangkang telur (Rahmawati dan Nisa 2015). Kerang simping termasuk kedalam golongan molusca dimana cangkangnya memiliki kandungan mineral yang tinggi, sehingga 
dengan penambahan tepung cangkang menyebabkan semakin tinggi pula kadar kerang simping maka akan abu biskuit.

Tabel 5. Kandungan Gizi Biskuit Cangkang Kerang Simping

\begin{tabular}{|c|c|c|c|}
\hline Parameter & $\begin{array}{l}\text { Biskuit cangkang } \\
\text { kerang simping } \\
\text { (Placuna } \\
\text { placenta) }(\%)\end{array}$ & $\begin{array}{lr}\text { Cookies } & \text { dari } \\
\text { cangkang } & \text { telur } \\
\text { (Rahmawati dan } \\
\text { Nisa 2015) }(\%)\end{array}$ & $\begin{array}{l}\text { Cookies cangkang kerang } \\
\text { simping } \\
\text { pleuronectes) (Amusium } \\
\text { al. 2011) (\%) }\end{array}$ \\
\hline Air & $3,76 \pm 0,30$ & 3,73 & $7,23 \pm 0,03$ \\
\hline Lemak & $33,23 \pm 1,56$ & - & $22,04 \pm 0,17$ \\
\hline Protein & $19,09 \pm 1,02$ & 6,88 & $16,12 \pm 0,03$ \\
\hline $\mathrm{Abu}$ & $4,39 \pm 1,33$ & 12,53 & $2,32 \pm 0,03$ \\
\hline Kalsium & $8,14 \pm 1,44$ & - & $6,57 \pm 0,09$ \\
\hline Fosfor & $1,63 \pm 0,23$ & - & $0,53 \pm 0,03$ \\
\hline
\end{tabular}

Keterangan:

-Data merupakan hasil rata-rata tiga ulangan \pm standar deviasi

Kadar kalsium biskuit cangkang kerang simping adalah $8,14 \%$, semakin banyak penambahan tepung cangkang kerang simping maka akan semakin tinggi kandungan kalsium yang terdapat didalam biskuit. Biskuit cangkang kerang simping termasuk kedalam biskuit yang kaya akan kalsium karena jumlah asupan kalsium yang dibutuhkan setiap harinya oleh tubuh hanya berkisar 600-1200 mg (Agustini et al. 2011). Sedangkan jumlah kandungan fosfor biskuit cangkang kerang simping adalah $1,63 \%$, sehingga kandungan biskuit cangkang kerang simping yang berasal dari perairan Indragiri Hilir mempunyai jumlah kalsium yang lebih besar dari pada jumlah fosfor. Tepung cangkang kerang simping dapat dijadikan sumber kalsium alternatif, namun penyerapannya belum optimal, hal ini disebabkan karena rasio kalsium dan fosfor dalam tepung tidak seimbang, yaitu kandungan kalsium yang tinggi $(17,23 \%)$ namun kandungan fosfor terlalu rendah $(0,79 \%)$ (Abidin et al. 2016) sehingga perlu ditambahkan sumber fosfor untuk dapat difortifikasikan dalam makanan (Agustini et al.2011).
Kandungan nutrisi cangkang kerang simping (Placuna placenta) yang berasal dari Perairan Indragiri Hilir dalam pembuatan biskuit lebih tinggi jika dibandingkan dengan cookies dari cangkang kerang simping (Amusium pleuronectes) hal ini disebabkan karena konsentrasi cangkang kerang simping yang berbeda dalam pembuatan biskuit dan cookies serta habitat dan spesies kerang simping yang berbeda pula.

\section{KESIMPULAN DAN SARAN}

Biskuit cangkang kerang simping yang terpilih berdasarkan uii hedonik dari 20 orang panelis semi terlatih adalah $50 \%$ kosentrasi tepung cangkang kerang simping. Berdasarkan nilai nutrisi biskuit cangkang kerang simping dari Perairan Indragiri hilir bahwa cangkang kerang simping dapat dijadikan sebagai alternative pangan yang mengandung kalsium.

\section{UCAPAN TERIMAKASIH}

Ucapan terimaksih kami sampaikan kepada Kemenristekdikti pada Hibah Penelitian Dosen Pemula Tahun 2013-2014 


\section{DAFTAR PUSTAKA}

Abidin H, Romadhon DYS. 2016. Fortifikasi Berbagai Jenis Tepung Cangkang Kerang Pada Proses Pembuatan Roti Tawar. J. Peng,\&Biotek. Hasil Pi 5(2):28-34. Agustini WN, Fahmi SA, Widiwati I,Sarwono A. Pemanfaatan Limbah Kerang Simping (Amusium pleuronectes) dalam Pembuatan Cookies Kaya Kalsium. JPHI XIV (1).

Almatsier Y. 2006. Prinsip Dasar Ilmu Gizi. Jakarta: PT. Gramedia Pustaka Utama.

Antara, N, dan Wartini, M. 2014. Aroma and Flavor Compounds. Tropical Plant Curriculum Project. Udayana University

Apandi I, Restuhadi F, Yusmarini. 2016. Analisis Pemetaan Kesukaan Konsumen (Consumer's Preference Mapping) Terhadap Atribut Sensori Produk Soygurt Dikalangan Mahasiswa Fakultas Pertanian Universitas Riau. Jom Faperta 3(1).

[BSN] Badan Standarisasi Nasional. 2011. Biskuit. SNI 2973-2011. Jakarta : Dewan Standarisasi Nasional.

Firmansyah, I. 2005. Gambaran Histopatologik Tulang Femur Tikus Putih (Rattus norvegicus) Pasca Ovariohisterektomi dengan Suplemen Kalsium Karbonat Dosis Tinggi. Fakultas Kedokteran Hewan Universitas Airlangga, Surabaya

Hiswati. 2002. Pengaruh penambahan tepung ikan nila merah (Oreochromis sp) terhadap karakteristik biskuit [skripsi]. Bogor: Program Sarjana Teknologi
Hasil Perikanan, Institut Pertanian Bogor.

Kemp SE, Hollowood T, and Hort J. 2009. Sensory Evaluation: A Practical Handbook. Wiley Blackwell, United Kingdom

Meilgard, M, Civille, GV, and Carr, BT. 2006. Sensory Evaluation Techniques Fourth Edition. CRC Press. USA

Midayanto, D., and Yuwono, S. 2014. Penentuan atribut mutu tekstur tahu untuk direkomendasikan sebagai syarat tambahan dalam standar nasional indonesia. Jurnal Pangan dan Agroindustri. 2: 4, 259-267 T. 2006. Sensory Evaluation Techniques Fourth Edition. CRC Press. USA.

Rahmawati AW, Nisa CF. 2015. Fotifikasi Kalsium Cangkang telur Pada Pembuatan Cookies (Kajian Kosentrasi Tepung Cangkang Telur dan Baking Powder). Jurnal Pangan dan Agroindustri 3(3):1050-1060.

Sada M. 1984. Fish Calsium. Infofish Marketing Digest. No I/84.

Saxby, M. 1996. Food Taints and OffFlavours. Springer Science and Business Media, New York

Soekarto, TS. 1990. Penilaian Organoleptik untuk Industri Pangan dan Hasil Pertanian. Bharata Karya Aksara, Jakarta

Susiwi, S. 2009. Penilaian Organoleptik. Universitas Pendidikan Indonesia. Bandung.

Tarwendah PI. 2017. Studi Komparasi Atribut Sensoris dan Kesadaran Merek Produk Pangan. Jurnal Pangan dan Agroindustri 5(2):6673.

Winarno FG. 2008. Kimia Pangan dan Gizi. Bogor : MBrio Press. 